\title{
Wilful Blindness or Blissful Ignorance? The United States and the Successful Denuclearisation of Iraq
}

The destruction of Iraq's nuclear capability by the International Atomic Energy Agency (IAEA) in 1992 is a remarkable example of successful nuclear counter-proliferation by the international community. Yet, in many respects, this was achieved in spite of the US Intelligence Community (IC) — and, indeed the US government as a whole — rather than because of it. Although the outcome of the inspections of Iraq's nuclear facilities was the desired one, the US intelligence agencies, principally the Central Intelligence Agency (CIA), consistently either failed to see or refused to see that Saddam Hussein's nuclear programme had been dismantled. From the Clinton years to the Bush administration, the CIA offered a worst case scenario analysis that focused on the small amount that was not known about Iraq's nuclear programme at the expense of the larger picture of successful dismantling. How could this great success - recognised at the time by the United Nations' nuclear inspectors—-be completely missed by the US intelligence?

This question has been the focus of numerous official and academic enquiries since 2004 . The 2005 Presidential Commission on the Intelligence Capabilities of the United States Regarding Weapons of Mass Destruction (also known as the Robb-Silberman Commission) laid the blame firmly on the CIA for failing to explain to policy makers that intelligence was inherently uncertain and inexact; however, there was no examination of the political use of intelligence by policy makers. Similarly the July 2004 report of the Senate Select Committee on Intelligence focused only on the CIA and not on policy makers' use of intelligence. ${ }^{1}$ Unofficial, and actually

\footnotetext{
${ }^{1}$ The Commission on the Intelligence Capabilities of the United States Regarding Weapons of Mass Destruction, March 31, 2005, http://www.gpoaccess.gov/wmd/pdf/full wmd report.pdf .Report of the Senate Committee on Intelligence on the U.S. Intelligence Community’s Prewar Intelligence Assessments on Iraq (henceforth SSCI 2004), July 9, 2004, http://intelligence.senate.gov/108301.pdf This first instalment of the Senate investigation examines
} 
more penetrating, accounts have rightly scrutinized the Bush administration's manipulation of intelligence on Iraq's nuclear and other WMD programmes and point out that, in the words of the Downing Street memo, "the intelligence and facts were...fixed around the policy."” This chapter seeks to enhance that analysis by taking a longer view and suggesting that US intelligence on Iraq had been hyper-politicized since the end of the 1991 Gulf War and throughout the Clinton years. To be sure, officials in the Bush administration were determined to find intelligence that might support their decision to go to war, but they were only accentuating trends that went back to the early 1990s when Iraq was first designated a "rogue state." The failure to witness the successful denuclearization of Iraq throughout the 1990s and into the twenty-first century was the result of an atmosphere in which intelligence and policy making toward Iraq had been hyper-politicised for a decade; where successive administrations had set Saddam up as one of America's most formidable adversaries to fill the "threat blank" that followed the end of the Cold War; and where this unchallenged assumption left US intelligence unable and/or unwilling to grasp the reality that the inspections by the IAEA's Iraq Nuclear Verification Office (INVO) had succeeded. ${ }^{3}$ In essence, the hypothesis presented here is that

failures on the part of the Intelligence Community. The second part of the report ('Phase II') was due to examine the political use of intelligence by policy makers. This was postponed until after the 2004 Presidential election and then delayed by Republicans on the Senate Intelligence Committee who sought to downplay the potential political impact of such a report. After some obstructionism by Republicans on the committee, it was not until 2008, with much less media attention, that the Phase II report on the political use of intelligence was released. See Senate Committee on Intelligence, Report on Whether Public Statements Regarding Iraq by U.S. Government Officials were Substantiated by Intelligence Information, June 2008, http://intelligence.senate.gov/080605/phase2a.pdf (all accessed 12 January 2011)

2 'The secret Downing Street memo', The Sunday Times, 1 May 2005, http:/www.timesonline.co.uk/tol/news/uk/article387374.ece (14 December 2010). For background, see John Diamond, The CIA and the Culture of Failure: U.S. Intelligence from the End of the Cold War to the Invasion of Iraq (Stanford University Press, Stanford, California, 2008): chapter 9. John Prados, Hoodwinked: The Documents That Reveal How Bush Sold Us a War (The New Press, New York 2006). Paul Pillar 'Intelligence, Policy and the War in Iraq' Foreign Affairs, March/April 2006: 15-27. James Bamford, A Pretext for War: $9 / 11$ and the Abuse of America's Intelligence Agencies (Doubleday Books, New York 2004).

\footnotetext{
${ }^{3}$ Senator Sam Nunn of Georgia identified the co-called "threat blank" in March 1990. See David Armstrong, 'Dick
} Cheney's Song of America' Harpers Magazine, October 2002: 77 
post-1991 US policy towards Iraq—rather than just post-9/11 policy—was overwhelmingly driven by politics rather than intelligence. While all intelligence remains imperfect and subjective, and rarely reveals a full and complete picture, the hypothesis of this chapter is that the identification of Iraq as the key 'rogue state', the political commitment to regime change in Baghdad from the mid-nineties onwards, and the long-standing context of regional energy security, led to an atmosphere of hyper-politicisation in Washington, where the only view that was ever considered was that Saddam Hussein retained not just the desire to use weapons of mass destruction (WMD) but that he actually possessed some of those weapons or the means to manufacture them. This chapter will examine the damaging effects that this hyper-politicisation had on US intelligence and policy making and on the international efforts to disarm Saddam.

In making this argument, two caveats seem necessary. The first, as implied above, is that I do not seek to argue that politicization can be erased completely or that the CIA and others should have pieced together the available information in such a way as to clearly reveal every facet of Baghdad's strategy and outlook. Such an outcome is rarely achievable in the world of intelligence. What concerns me is that, in the evidence currently available, the possibility of success was never considered despite the serious weight of evidence from the inspections regime-INVO in particular - suggesting that the analyses of the US IC were superficial in many ways. There appears to have been no attempt to challenge existing assumptions despite signs that should have prompted a degree of reassessment.

A second caveat, related to this, is the issue of what sources are currently available to those seeking to understand why the CIA made the judgements that it did during the 1990s and early 2000s. Inevitably, any judgements made here are based on an incomplete documentary record and may be disproved as more material is released. It seems unlikely that the unclassified CIA 
reports to Congress that I quote later in this chapter are not representative of the classified versions of those reports; material is usually withheld to avoid compromising sources rather than because classified reports make significantly different overall judgements to their unclassified counterparts. Nevertheless, there is a vast amount of material currently unavailable. This chapter seeks to pose questions that intelligence historians should, in my view, return to in future and to present a hypothesis that opens up future avenues for discussion as more materials are declassified. That said, there is some useful material available already, which permits us to begin the analysis and draw tentative conclusions.

As Graham Pearson has noted, there has been a reluctance in some of the ongoing international arms control negotiations to draw on the Iraq experience. ${ }^{4}$ This is particularly the case for the nuclear issue: references to INVO in memoirs by former inspectors and in popular and academic accounts are few and far between. ${ }^{5}$ Its work has been obscured by the general focus on the travails of the United Nations Special Commission (UNSCOM), which searched for chemical and biological weapons (CBW) and had to deal with concealment and deception efforts by the Iraqis. Yet despite the controversy that the inspections process generated, it was remarkably successful; INVO dismantled Saddam's nuclear capability, while UNSCOM removed his

\footnotetext{
${ }^{4}$ Graham S. Pearson, The Search for Iraq's Weapons of Mass Destruction: Inspection, Verification and NonProliferation (Palgrave Macmillan, New York 2005):70

${ }^{5}$ See for instance Charles Duelfer, Hide and Seek: The Search for Truth in Iraq (Public Affairs, New York 2009). Richard Butler, The Greatest Threat: Iraq, Weapons of Mass Destruction, and the Crisis of Global Security (Public Affairs, New York 2000). Scott Ritter, Endgame: Solving the Iraq Crisis (Simon \& Schuster, New York 1999). Hans Blix, Disarming Iraq: The Search for Weapons of Mass Destruction (Bloomsbury, London 2004). Given Blix's position as head of INVO, his book contains more information on INVO than the other accounts, although it is not exclusively about the nuclear inspections. Pearson's Search for Iraq's Weapons of Mass Destruction deals only with UNSCOM and CBW. The following contain some discussion of UNSCOM but virtually none on INVO: Dilip Hiro, Iraq: A Report from the Inside (Granta Books, London 2003); James Risen State of War: The Secret History of the CIA and the Bush Administration (Free Press, New York 2006); Nick Ritchie and Paul Rogers, The Political Road the War with Iraq: Bush, 9/11 and the Drive to Overthrow Saddam (Routledge, Oxon and New York 2007). Neither UNSCOM nor INVO are mentioned at all in Robert Jervis' Why Intelligence Fails: Lessons from the Iranian Revolution and the Iraq War (Cornell University Press, Ithaca and London 2010).
} 
chemical and biological weapons and infrastructure. ${ }^{6}$ There is much for US intelligence to learn from this, both in terms of its analysis of potential threats and what kind of a role it should —or should not—play in the practical task of disarmament. More often than not, however, intelligence only informs policy when it supports the pre-existing preferences of policy makers. The United States' pursuit of regime change in Iraq from the mid-nineties onwards meant that the Clinton and Bush administrations either would not or could not accept the nullification of Baghdad's nuclear programme thus continuing the cycle of policy-driven intelligence, which culminated in regime change in 2003 . $^{7}$ Without a doubt, Saddam's erratic co-operation with the UNSCOM inspectors nourished suspicions that he retained chemical and/or biological weapons; nevertheless, as Hans Blix, former director of INVO, points out, there were also other reasons, unrelated to maintaining WMD, why Saddam might have sometimes denied access to UNSCOM inspectors; we shall come to these later. ${ }^{8}$ In the end, it was not until well after the 2003 invasion when the final team of inspectors failed to uncover any banned weapons programmes that the belated recognition of the success of INVO (and UNSCOM) came. This chapter will argue that while improvements in intelligence analysis are always salutary, we should be wary of assuming that better intelligence will result in more effective non-proliferation efforts. As the deliberate inequities of the Nuclear Non-Proliferation Treaty affirm, nuclear policy is always subject to a political power calculus that transcends intelligence.

\footnotetext{
${ }^{6}$ For a summary of the achievements of both INVO and the United Nations Special Commission (UNSCOM), which inspected chemical and biological sites, see the Report of the First Panel Established Pursuant to the Note By the President of the Security Council on 30 January 1999 (S/1999/100), Concerning Disarmament and Current and Future Ongoing Monitoring and Verification Issues (henceforth the Amorim Report), 27 March 1999, http://www.un.org/Depts/unmovic/documents/Amorim\%20Report.htm (13 May 2010).

${ }^{7}$ Charles Duelfer makes the point that the Clinton administration did not want Iraq to be found in compliance with the UN resolutions on disarmament. See Hide and Seek: 164

${ }^{8}$ See Blix, Disarming Iraq: 26, 36, 265-6.
} 


\section{"Rogue States", the Middle East and the Post-Soviet "Threat Blank"}

The origins of the political elevation of the Iraqi threat lie in the end of the Cold War. In March 1990, Senator Sam Nunn, a Democrat from Georgia and Chair of the Senate Armed Services

Committee, told fellow senators that there was a "threat blank" in the Bush administration's proposed \$295 billion defence budget and that the Pentagon's “basic assessment of the overall threat to our national security" was "rooted in the past." There had been tumultuous changes in the world since 1989 but "the development of a new military strategy that respond[ed] to these changes in the threat ha[d] not yet occurred." 9 Threatened with cuts in defence expenditure, the military and the Bush administration knew that it would have to fill the "threat blank" so as to avoid having cuts foisted upon it by Congress. Although some reductions would be inevitable, the cuts could be minimised if the military itself could shape the process by presenting Congress with a new post-Cold War global strategic blueprint to guide future planning and appropriations. ${ }^{10}$ This would mean finding new, post-Soviet justifications for the Pentagon's substantial budget and a search for new strategic adversaries. As Colin Powell, Chair of the Joint Chiefs of Staff (JCS), quipped in 1991, "I'm running out of villains. I'm down to Castro and Kim Il Sung."11

Powell had recognised as early as 1987 that changes in posture and force structure would soon be necessary and when he became Chair of the JCS in 1989, he accelerated planning for post-Cold

\footnotetext{
${ }^{9}$ Cited in Armstrong, 'Dick Cheney's Song of America': 77

${ }^{10}$ Colin Powell, A Soldier's Way: An Autobiography (Arrow Books, London 1995): 451.

${ }^{11}$ Powell quoted in Karl Kaysen, Robert S. McNamara and George W. Rathjens, 'Nuclear Weapons After the Cold War' Foreign Affairs, Fall 1991: 96. On the search for new strategic adversaries, see Lorna S. Jaffe, The Development of the Base Force 1989-1992, (Joint History Office of the Chairman of the Joint Chiefs of Staff, July 1993): 9-11. Michael Klare, Rogue States and Nuclear Outlaws: America's Search for a New Foreign Policy (Hill and Wang, New York, 1995): 12-16. Eric V. Larson, David T. Orletsky and Kristin J. Leuschner. Defense Planning in a Decade of Change: Lessons from the Base Force, Bottom-Up Review and Quadrennial Defense Review (RAND, Santa Monica, Arlington, Pittsburgh 2001) : 8.
} 
War strategic scenarios, which would permit the retention of a military establishment still large enough to ensure Washington's status as a global superpower. He eventually settled on the socalled 'Base Force', which signified the level below which US forces could not go if the country was to maintain its position as the global superpower. The Base Force would be able to fight and win two simultaneous major regional conflicts resembling Desert Storm. ${ }^{12}$ The culmination of Powell's thinking was the National Military Strategy of January 1992, which envisioned a strategic posture founded upon a framework of regional contingencies. "We will, of course, deter and defend against strategic nuclear attacks... (and) retain the potential to defeat a global threat" the strategy stated; "[h]owever, our plans and resources are primarily focused on deterring and fighting regional rather than global wars." 13 Such contingencies would most likely take the form of developing states armed with WMD threatening regional stability and US interests. Saddam Hussein's invasion of Kuwait on 2 August 1990 seemed to confirm this premise and Iraq became the exemplar of the regional aggressor. ${ }^{14}$

However, Iraq was an anomalous case. The regional contingencies framework, which was based on fighting two Iraq-type conflicts simultaneously vastly overstated the potential of postDesert Storm regional aggressors to challenge the United States. Even Powell himself

\footnotetext{
${ }^{12}$ See National Military Strategy of the United States (henceforth NMS 1992), 1 January 1992, http://www.dtic.mil/cgi-bin/GetTRDoc?AD=ADA338837\&Location=U2\&doc=GetTRDoc.pdf (21 May 2010): 1718. Colin L. Powell, 'U.S. Forces: Challenges Ahead' Foreign Affairs, Winter 1992-93: 41-44. Jaffe, Development of the Base Force: 21-22. Klare, Rogue States and Nuclear Outlaws: 28-34.

${ }^{13}$ NMS 1992: 11

${ }^{14}$ In his speech at the Aspen Institute, less than 24 hours after the invasion, Bush stated that "the brutal aggression launched last night against Kuwait illustrates my central thesis." See Remarks at the Aspen Institute Symposium in Aspen, Colorado, 2 August 1990, Public Papers of George Bush, George Bush President Library and Museum, http://bushlibrary.tamu.edu/research/public papers.php?id=2128\&year=1990\&month=8 (21 May 2010). The 1992 National Military Strategy also pointed to North Korea "and perhaps even a hostile Iran" as potential regional threats. See 1992 National Military Strategy: 3.
} 
commented in April 1991 that he would be "very surprised if another Iraq occurred." ${ }^{15}$ As Michael Klare, David Callahan and Lawrence J. Korb have demonstrated, far from being representative of potential regional aggressors, the Iraq of 1990 was an anomalous case, an exceptional rather than a typical military threat. ${ }^{16}$ Baghdad had been stronger militarily than all other potential regional aggressors (such as Iran, Syria, Libya and North Korea) and was unique in its proximity to US vital interests. The only two potential aggressors that came close to Iraqi strength in 1990 were Syria and North Korea but both were balanced by powerful proAmerican neighbours meaning that external territorial aggression was unlikely. ${ }^{17}$ Iran's 1991 defence budget of $\$ 3.2 \mathrm{~B}$ was a long way behind the $\$ 8.6 \mathrm{~B}$ Iraq spent in 1990. Yet despite Iraq's strength it was defeated with ease by coalition forces—-but Powell's Base Force, formally unveiled in 1992 after the military destruction of Iraq, was designed not just to fight one aggressor resembling pre-Desert Storm Iraq, but two simultaneously; a prospect that even Powell had acknowledged was remote indeed. However, this inflated calculation of the strength of regional aggressors - and the plan to fight two of them simultaneously — was necessary to help justify relatively high US force levels in the post-Cold War world. Powell had called the new military structure the 'Base Force' to indicate that this was a level below which US forces could not fall if the United States was to maintain its position as the world's sole superpower. Thus the prototype of the pre-Desert Storm Iraq helped to rationalise US

\footnotetext{
${ }^{15}$ Cited in David Callahan, 'Saving Defense Dollars', Foreign Policy, No. 96 (Autumn 1994): 102

${ }^{16}$ Klare, Rogue States and Nuclear Outlaws: 130-69. Callahan, 'Saving Defense Dollars': 94-112. Lawrence J. Korb, 'Our Overstuffed Armed Forces', Foreign Affairs, November/December 1995: 22-34

${ }^{17}$ North Korea came closest to Iraq's position in 1990 but had only had only half the population of its southern neighbour and one sixteenth of its GDP; not to mention the serious questions about the combat readiness of North Korea's military. Callahan, 'Saving Defense Dollars': 102-3. On the combat readiness (or lack of it) of the North Korean army see John Feffer, North Korea, South Korea: U.S. Policy at a Time of Crisis (Seven Stories Press, New York, 2003): 66-70.
} 
force levels in the post-Soviet world where there was now no other obvious major adversary to justify the largest military establishment in the world.

The Clinton administration fully accepted the regional contingency framework in its own Bottom-Up Review of the military in $1993 .{ }^{18}$ In 1994, Clinton's National Security Advisor, Anthony Lake, published an article in Foreign Affairs in which he identified Iraq, Iran, North Korea, Cuba and Libya as "backlash states" because of their "aggressive and defiant" behaviour. ${ }^{19}$ Iraq and Iran were the two most immediate problems because of their proximity to critical American interests, Lake stated, and he outlined a policy of "dual containment" of Baghdad and Tehran. ${ }^{20}$ Increasingly, the "backlash states" became known as the "rogue states" in the administration's public discourse and the leading rogue state was Iraq. ${ }^{21}$ As General Wesley Clark comments, "the threat from Iraq came to assume a major role in U.S. defense planning" and "scenarios from hypothetical war in Iraq were used in requirements studies for weapons procurements, force designs and training.,"22

The political utility of the rogue state narrative was not the only reason US policy towards Iraq became so politicized. No analysis of US policy towards Iraq and the Middle East would be complete without considering the importance of energy security. Since the end of the Second World War, US interest in Iraq and the Middle East in general was motivated by its desire to

\footnotetext{
${ }^{18}$ Les Aspin, Secretary of Defense, Report on the Bottom-Up Review, October 1993, http://www.dtic.mil/cgibin/GetTRDoc?AD=ADA359953\&Location=U2\&doc=GetTRDoc.pdf?type=FinjanDownload\&slot $=00000039 \&$ id $=00000038 \&$ location $=80$ F3FD65 $(21$ May 2010). Larson et. al. Defense Planning in a Decade of Change: 41-81.

${ }^{19}$ Anthony Lake, 'Confronting Backlash States' Foreign Affairs, March/April 1994: 45.

${ }^{20}$ Lake 'Confronting Backlash States': 47-52

${ }^{21}$ Klare, Rogue States and Nuclear Outlaws: 127

${ }^{22}$ General Wesley K. Clark, Winning Modern Wars: Iraq, Terrorism, and the American Empire (Public Affairs, New York 2003): 6
} 
preserve access to the region's petroleum resources and to ensure a reliable supply of (relatively) cheap oil. (During the Cold War, the corollary to this was minimizing Soviet influence in the region). ${ }^{23}$ Iraq's possession of the second largest reserves of oil in the world made it a key producer; guaranteeing access to cheap oil would yield many benefits for the United States. ${ }^{24}$ It would facilitate national economic, political and military power, as well as power over others, including allies, who were not in a position to guarantee the supply of their own oil. In short, maintaining a position as the dominant outside power in the Middle East was an essential component of global superpower status. Over the decades, US policy towards Iraq had been determined by the imperatives of energy security and preventing these vital resources from falling into hostile hands. After the 1979 Islamic revolution in Iran, Saddam Hussein became a trusted American ally and received military, financial and intelligence aid from Washington after his invasion of Iran. But when Saddam subsequently invaded Kuwait, another oil-rich country, the United States took the lead in repelling the attack because to acquiesce would have left the dictator in control of two oil rich countries in the region. Saddam would become the dominant power in the Mid East, a position the United States wanted to maintain for itself. ${ }^{25}$ This, then, was the context in which US policy makers and intelligence analysts viewed Iraq in the early nineties: as the leading 'rogue state' with a credible military capability—including an active nuclear programme —and an appetite for expansionism in a region that the US itself had sought for decades to dominate.

\footnotetext{
${ }^{23}$ For a comprehensive overview of US energy and security policy to the Middle East, see Daniel Yergin, The Prize: The Epic Quest for Oil, Money and Power (Simon \& Schuster, New York 2009): 371-774.

${ }^{24}$ For statistics on global energy reserves, see Michael Klare, Resource Wars: The New Landscape of Global Conflict (Owl Books, New York 2001): 45.

${ }^{25}$ Steven Hurst The United States and Iraq Since 1979: Hegemony, Oil and War (Edinburgh University Press, Edinburgh 2009): 83.
} 
The tentative pursuit of the ousting of Saddam (though not the Baathist regime) began in early 1992. Saddam had clung to power during the war but the Bush administration realised that he would no longer support US objectives in the region. To encourage a pro-American coupalthough not the collapse of the entire regime-Bush signed a covert finding authorizing the CIA to hire the Rendon Group, a Washington DC firm specializing in "perception management" services, on a one hundred million dollar contract in 1992 to "create the conditions for removal of Saddam Hussein from power" in the expectation that the Iraqi dictator would be deposed before long from within, preferably through a pro-Western military coup. ${ }^{26}$ This was not to be, but the covert efforts to unseat Saddam continued after Clinton took office. In August 1993, Ahmed Chalabi, the leader of a new Iraqi opposition group called the Iraqi National Congress (INC) that had been created by the Rendon Group the previous year, received a letter from Vice President Al Gore implying support for a policy ultimately directed towards regime change. "I assure you that we will not turn our backs on the Kurds or the other Iraqi communities subjected to the repression of Saddam Hussein's regime" Gore wrote. He stressed the administration's support for humanitarian relief efforts but also suggested that it might be prepared to go beyond this:

Secretary Christopher, National Security Advisor Lake, and I made a solid commitment to INC representatives in our meetings, and we pledged our support for a democratic alternative to the Saddam Hussein regime. I can assure you that the U.S. intends to live up to these commitments and to give whatever additional

\footnotetext{
${ }^{26}$ James Bamford, 'The Man Who Sold the War' Rolling Stone, 17 November 2005, http://www.rollingstone.com/politics/story/8798997/the man_who_sold the_war/ (17 August 2009). Andrew Cockburn and Patrick Cockburn, Saddam Hussein: An American Obsession (Verso, London, 2002): 12-3, 31-57. Jane Mayer, 'The Manipulator' The New Yorker, 7 June 2004, http://www.newyorker.com/archive/2004/06/07/040607fa fact1 (21 December 2009) Hiro, Iraq: 71-94. Christian Alfonsi, Circle in the Sand: Why We Went Back to Iraq (Doubleday, New York 2006): 193-4, 234-7
} 
support we can reasonably provide to encourage you in your struggle for a democratic Iraq. $^{27}$

In November 1993, four months after he sent the letter, Chalabi presented the administration with a four stage war plan titled 'The End Game' and in response Clinton authorized a covert CIA operation based in Iraqi Kurdistan to work with Iraqi exiles in the INC and the Iraqi National Accord (INA - also established by the Rendon Group) to organize a coup against Saddam. ${ }^{28}$ Thus while Clinton's official policy towards Iraq was containment, the administration also quietly supported opposition-led efforts to oust Saddam. The CIA's station in northern Iraq sponsored two coups by the Iraqi opposition in 1995 and 1996. Chalabi's group organized an insurrection in the north to begin in March 1995, but the CIA withdrew support at the last minute after a rival in the INA convinced Washington that the plan would provoke a massive military backlash from Baghdad and the covert operation would become an overt bloodbath involving the United States. When the rebellion went ahead anyway it failed spectacularly. An anti-Saddam coup was subsequently planned by the INA for June 1996 but that plot failed after being infiltrated by Iraqi intelligence-a point we shall return to later. ${ }^{29}$

Even in the early nineties both Republicans and Democrats saw the advantages of ousting Saddam — although not at this stage his whole regime. Once a key ally, Saddam's pursuit of regional hegemony had made him a liability. What concerns us here is whether the efforts to

\footnotetext{
${ }^{27}$ The letter was re-printed in the Congressional record when Chalabi presented it to the Senate Committee on Foreign Relations after testifying in March 1998. See 'Iraq: Can Saddam Be Overthrown?' Hearing Before the Subcommittee on Near Eastern and South Asian Affairs of the Committee on Foreign Relations, United States Senate, One Hundred Fifth Congress, March 2, 1998, http://frwebgate.access.gpo.gov/cgibin/getdoc.cgi?dbname=105_senate_hearings\&docid=f:47150.pdf (22 February 2009): 15

${ }^{28}$ Seymour Hersh, Chain of Command (Penguin Books, London, 2005): 164. Robert Baer, See No Evil: The True Story of a Ground Soldier in the CIA's War on Terrorism (Arrow Books, London, 2002): 255-63, 299-319.

${ }^{29}$ For a full account, see Hiro, Iraq: 71-136; Ritter, Endgame: 131-46.
} 
remove him were politically-driven or intelligence-led or a combination of both. Did these efforts continue because intelligence suggested that Saddam retained WMD or did the policy transcend the work of the UN weapons inspectors?

\section{The Iraq Nuclear Verification Office (INVO) and Saddam's Nuclear Programme}

The CIA had failed to see the full scope of Saddam's nuclear programme during the $1980 \mathrm{~s} .{ }^{30} \mathrm{It}$ was only with the bombing of Tarmiya, twenty-five miles north of Baghdad, in the 1991 war that the nuclear programme came to light. With assistance from US intelligence, the INVO inspectors began to examine the site in May 1991. What became apparent quickly was that Iraq had not just one uranium enrichment experiment but three. The entire programme had been undetected because Iraqi scientists had replicated the Manhattan Project and used an oldfashioned process known as electromagnetic isotope separation (EMIS). This was a relatively slow and labour-intensive process that had been abandoned by other nuclear powers so US intelligence never considered that Saddam might use it. ${ }^{31}$ Moreover, after the invasion of Kuwait, Iraq had also planned a 'crash' nuclear programme in which highly enriched uranium (HEU) would be diverted from IAEA safeguards and used for a weapon—although the beginning of the $\mathrm{UN}$ inspections prevented this from ever taking place. ${ }^{32}$

Why the CIA failed to recognise that Saddam had a nuclear programme is beyond the scope of this chapter. ${ }^{33}$ Suffice it here to say that, despite this, the INVO nuclear disarmament

\footnotetext{
${ }^{30}$ Diamond, CIA and the Culture of Failure: 179-184.

${ }^{31}$ James Risen, State of War: The Secret History of the CIA and the Bush Administration (Free Press, New York, 2006): 96-7

32 Fourth consolidated report of the Director General of the International Atomic Energy Agency under paragraph 16 of Security Council resolution 1051 (1996) (henceforth IAEA 1997), Part Two, http://www.iaea.org/OurWork/SV/Invo/reports/s_1997_779.pdf : 48 (22 May 2010)

${ }^{33}$ For some discussion on this see Diamond, CIA and the Culture of Failure: 184-6
} 
programme was hugely successful. Blix described the early results as "spectacular" and with good reason. ${ }^{34}$ What the inspectors found initially was "a very well-funded programme aimed at indigenous development and exploitation of technologies for the production of weaponusable material and the development and production of nuclear weapons, with a target date of 1991 for the first weapon." ${ }^{, 35}$ By 1992, they had essentially dismantled this programme, although the removal of weapon-usable material continued until 1994. The IAEA reported "a comprehensive campaign of destruction, removal and rendering harmless of the practical assets of Iraq's clandestine nuclear programme. ${ }^{, 36}$ This included accounting for the entire inventory of HEU that had been destined for the 'crash' programme. ${ }^{37}$ Saddam had decided that his nuclear ambitions were secondary to the prime objective of ending sanctions and ensuring the survival of the regime. ${ }^{38}$ All that was left was "the intent to retain the intellectual capital" necessary to one day revive the nuclear programme when sanctions were lifted.$^{39}$ As a result of INVO's success, it reached a "point of diminishing returns" through inspections and in 1994 it implemented its Ongoing Monitoring and Verification (OMV) plan with the establishment of the Nuclear Monitoring Group (NMG), which would have a continuous presence in Iraq. ${ }^{40}$ When the UNSCOM chemical and biological inspections became particularly fractious in October 1997, Iraq continued to work with the IAEA nuclear monitors. When Baghdad

\footnotetext{
${ }^{34}$ Blix, Disarming Iraq: 23

${ }^{35}$ IAEA 1997: 18

${ }^{36}$ Ibid: 16

${ }^{37}$ Ibid: 48

${ }^{38}$ Comprehensive Report of the Special Advisor to the Director of Central Intelligence on Iraq's Weapons of Mass Destruction (henceforth Duelfer Report), 30 September 2004, Key Findings, http://www.cia.gov/reports/generalreports-1/iraqwmd2004/Comp_Report_Key_Findings.pdf : Section on Regime Strategic Intent: 1

${ }^{39}$ Duelfer Report, Nuclear section: 1

${ }^{40}$ IAEA 1997: 22, 17
} 
declared that it would no longer deal with U.S. nationals in the UNSCOM team, it also announced that "[a]11 IAEA staff, inspectors and experts will be welcome as usual." The same was true of the subsequent crisis a year later. ${ }^{41}$

However, the inspection and verification process for all WMD came to an end in late 1998 when the Clinton administration decided to bomb Iraq in December after a series of stand-offs during which UNSCOM inspectors had been denied access to certain sensitive sites. This led to disarray at the UN Security Council. There were differences of opinion amongst its members as to the future of the sanctions regime, which was eroding, and the future of the chemical and biological weapons inspections, particularly of certain sensitive sites such as Presidential residences. ${ }^{42}$ However, the destruction of Iraq's nuclear programme was still widely accepted by UN staff and inspectors. In 1999, the United Nations set up a panel led by Brazilian Ambassador to the UN, Celso Amorim, to examine the findings to date of the weapons inspectors, with a view to re-establishing an UNSCOM and IAEA presence in Iraq. All twenty members of the panel were former inspectors (eleven from UNSCOM and three from the IAEA). ${ }^{43}$ They reported that the IAEA had "been able, in the course of eight years of extensive inspection activities, to develop a technically coherent picture of Iraq's clandestine nuclear programme." By the end of 1992, the IAEA had destroyed the components of the programme and by February 1994, it had removed all weapon-usable material from Iraq. Moreover:

\footnotetext{
${ }^{41}$ Blix, Disarming Iraq: 33-4. See also Butler, Greatest Threat: 187.

${ }^{42}$ Ritter, Endgame: 190-98. Nick Ritchie and Paul Rogers, The Political Road to War With Iraq (Routledge, London 2006): 27-30. Butler, Greatest Threat: 89-90, 200-14.

${ }^{43}$ Howard Diamond, 'UN Creates New Panel to Review Iraqi Disarmament' Arms Control Today, January/February 1999, http://www.armscontrol.org/print/447 (23May 2010)
} 
On the basis of its findings, the Agency is able to state that there is no indication that Iraq possesses nuclear weapons or any meaningful amounts of weapon-usable nuclear material or that Iraq has retained any capability (facilities or hardware) for the production of such material. ${ }^{44}$

Individual inspectors — with quite different views on how to deal with Saddam Hussein — spoke on the record about how the country had essentially been disarmed of all its WMD, not just nuclear material. Rolf Ekeus was the Executive Chairman of UNSCOM from 1991-97. In 2003 he supported the US-led invasion of Iraq on the grounds that Iraq retained researchers and engineers who had worked on WMD programmes - in other words it aspired to develop WMD — but it had not retained the weapons themselves. Ekeus acknowledged in 2000 that the inspectors had been "highly successful.... In my view there are no large quantities of weapons. Rather Iraq has been aiming to keep the capability to start up production immediately should it need to." ${ }^{45}$ Scott Ritter, an UNSCOM inspector for seven years, agreed. In 1999, Ritter published an account of the inspections process that dealt with Iraqi attempts to conceal WMD but also with the ultimate success of the inspections: what remained was "little more than the bare bones of the of massive [pre-1991] projects... Despite all of Iraq's efforts to conceal, obfuscate and distort the truth, [we] managed to dispose of the vase majority [of WMD]."46 Charles Duelfer, Deputy Executive Chair of UNSCOM from 1993-2000, gave strong support

\footnotetext{
${ }^{44}$ Report of the First Panel Established Pursuant to the Note by the President of the Security Council on 30 January 1999 (S/1999/100), Concerning Disarmament and Current and Future Ongoing Monitoring and Verification Issues (henceforth Amorim Report), 27 March 1999, http://www.un.org/Depts/unmovic/documents/Amorim\%20Report.htm (23 May 2010)

${ }^{45}$ Rolf Ekeus, 'Iraq's Real Weapons Threat' Washington Post, 29 June 2003. J. Peter Scoblic and Matthew Rice, 'Shifting Priorities: UNMOVIC and the Future of Inspections in Iraq: An Interview with Ambassador Rolf Ekeus' Arms Control Today, March 2000, http://www.armscontrol.org/act/2000_03/remr00 (23 May 2010)

${ }^{46}$ Ritter, Endgame: 127
} 
to the 2003 invasion of Iraq but, like Ekeus, this was because he believed that Saddam retained the desire for WMD, not because he actually possessed the proscribed weapons. Duelfer's 2004 report on Iraq's WMD — the final official US report to be written on the subjectacknowledged that Saddam's “ability to reconstitute a nuclear weapons program progressively decayed after [1991]." This was because the primary goals of the regime were to lift sanctions and to secure itself. ${ }^{47}$

This should not be entirely surprising because the inspections were intrusive and were backed up by the threat of force. Inspectors were allowed to conduct invasive no-notice inspections of any site inside Iraq. ${ }^{48}$ This was combined with the toughest sanctions regime in history, the objective of which was to prevent Iraq from importing any material or equipment that could be used for the production of WMD. This included a great deal of dual-use material, which meant that the Iraqi people were deprived of many of their basic material needs, including medicines and medical equipment. The sanctions devastated the Iraqi economy and society. The UN's humanitarian co-ordinator for Iraq, Denis Halliday, resigned in protest over what he claimed were "genocidal sanctions" that were leading to the deaths of six thousand Iraqi infants per month. ${ }^{49}$ As a result the sanctions regime was much-maligned and the humanitarian impact led to discord and uncertainty on the Security Council. In terms of Iraq's WMD, however, the sanctions broke the industrial backbone of the country and made WMD reconstitution

\footnotetext{
${ }^{47}$ Duelfer Report, Nuclear section: 1 and Regime Strategic Intent section: 1.

${ }^{48}$ Duelfer, Hide and Seek: 79, 95. Scott Ritter, 'The truth of the UK's guilt over Iraq' Guardian, 27 November 2009, http://www.guardian.co.uk/commentisfree/2009/nov/27/truth-uk-guilt-iraq-chilcot (23 May 2010). Butler, Greatest Threat: 40.

${ }^{49}$ Eric Black, 'Ex-U.N. aide decries "genocidal sanctions"” Star-Tribune (Minneapolis) 15 March 1999. Rahul Mahajan, Full Spectrum Dominance: U.S. Power in Iraq and Beyond (Seven Stories Press, New York 2003): 92106
} 
unrealistic. ${ }^{50}$ Even though the sanctions had begun to erode by the turn of the century it would take years, if not decades, for Saddam to re-build the necessary infrastructure. David Kay, a former UNSCOM inspector who strongly supported the 2003 invasion, told the Senate Armed Services Committee in January 2004 that he believed that the Iraqis had not simply moved large WMD stockpiles to a neighbouring country before the invasion because they did not have the capability to produce such stockpiles in the first place. $^{51}$

It was not just INVO that succeeded in disarming Saddam. UNSCOM also achieved much success in disarming Iraq of its CBW. To be sure, UNSCOM had to face greater denial and deception efforts on the part of Saddam. ${ }^{52}$ The actual weaponization of biological agents - as opposed to simply having a BW programme- -was unknown until the 1995 defection of General Hussein Kamel, Saddam's son-in-law who had been in charge of all WMD programmes. ${ }^{53}$ Nevertheless, Iraq had been disarmed of most of its known CBW and the main production facilities destroyed. According to the Amorim Report compiled by former inspectors, "the bulk of Iraq's proscribed weapons programmes has [sic.] been eliminated.",54

Yet, the US Intelligence Community was disinclined to accept this. The best intelligence coming out of Iraq - from those who had seen the WMD programmes, or what was left of

\footnotetext{
${ }^{50}$ Blix, Disarming Iraq: 57.

${ }^{51}$ David Kay, Testimony to the Senate Armed Services Committee (henceforth Kay testimony), 28 January 2004, http://www.globalresearch.ca/articles/KAY401A.html (23 May 2010)

${ }^{52}$ See Butler, Greatest Threat: 160-1, 164, 204, 206-7.

${ }^{53}$ Blix, Disarming Iraq: 29-30. John Barry, 'The Defector's Secrets' Newsweek, 3 March 2003: 6. For the transcript of Kamel's debriefing with UNSCOM and the IAEA, see http://www.fair.org/press-releases/kamel.pdf (23 May 2010).

${ }^{54}$ The Amorim Report stated that UNSCOM had “obtained a good understanding of the major parameters of Iraq's CW programme"; that the prime CW development and production complex had been dismantled; and that large quantities of $\mathrm{CW}$ had been destroyed. In addition the declared facilities of Iraq's BW programme had been destroyed as well as substantial amounts of BW.
} 
them, first hand - was not fully accepted by the US IC, which, in general, chose to emphasize what was not known about Iraq's WMD rather than what was. From 1998 onwards, the CIA delivered a Congressionally mandated biannual Unclassified Report to Congress on the Acquisition of Technology Related to Weapons of Mass Destruction and Advanced Conventional Munitions. ${ }^{55}$ These reports focused heavily on the rogue states, Iraq, Iran and North Korea. They contained no indication that, for the most part, Iraq had been denuclearised (and also stripped of most of its CBW). Tending towards a worst-case scenario, the reports focused on the small amount of material that was unaccounted for rather than the bigger picture of success. Despite the dismantling of the nuclear programme constituting the UN's biggest success, in the first Unclassified Report of 1998, the CIA stated that:

Iraq continues to hide documentation, and probably some equipment, relating to key aspects of past nuclear activities. After years of Iraqi denials, the IAEA was able to get Iraq to admit to a far more advanced nuclear weapons program and a project based on advanced uranium enrichment technology. However, Baghdad continues to withhold significant information about enrichment techniques, foreign procurement, and weapons design. ${ }^{56}$

Although not all this information was historically inaccurate, it created the impression that the nuclear issue was unresolved by 1998. What was not stated was that the nuclear program had been discovered and dismantled by 1992, as documented in the INVO and the OMV reports.

\footnotetext{
${ }^{55}$ These reports are listed under 'Recurring Reports' at https://www.cia.gov/library/reports/archived-reports1/index.html (29 May 2010)

${ }^{56}$ Unclassified Report to Congress, January-June 1998, https://www.cia.gov/library/reports/archived-reports1/jan jun1998.html\#acquisition (28 May 2010)
} 
At the end of 1998, the UN inspectors were withdrawn from Iraq at the behest of the Clinton administration, which planned to bomb suspected WMD sites in response to Iraq's denial and deception efforts. After Operation Desert Fox, the inspectors would not return to Iraq for another five years. In a 2000 report to Congress, the CIA stated that "[h]aving lost this on-theground access, it is more difficult for the UN or the US to accurately assess the current state of Iraq's WMD programs." As a result the Agency tended to simply assume that Saddam was reconstituting WMD: a June 1999 report stated that although "we do not have any direct evidence that Iraq has used the period since Desert Fox to reconstitute its WMD programs... given its past behaviour, this type of activity must be regarded as likely" (emphasis added). Regarding the nuclear programme, "we were already concerned about a reconstituted nuclear weapons program, [but] our concerns were increased last September when Saddam publicly exhorted his 'Nuclear Mujahidin' to 'defeat the enemy"'; rhetoric that the CIA seems to have taken literally despite the weight of evidence against it from the IAEA. ${ }^{57}$

Nor did the reports to Congress mention evidence provided in 1995 by General Hussein Kamel, the man responsible for all of the country's weapons programmes (also Saddam's sonin-law), who defected to Jordan and was debriefed by the IAEA, UNSCOM and the CIA. Kamel told his debriefers of Saddam's decision to abandon his weapons in the early nineties as a result of pressure from the inspections regime: "All weapons_-biological, chemical, missile, nuclear were destroyed" he said, adding that the inspections were working well in Iraq: "You have [an] important role in Iraq. You should not underestimate yourself. You are very effective

\footnotetext{
${ }^{57}$ Unclassified Report to Congress, July-December 2000, Section on Iraq, https://www.cia.gov/library/reports/archived-reports-1/july_dec2000.htm\#4 Unclassified Report to Congress, January-June 1999, Section on Iraq, https://www.cia.gov/library/reports/archived-reports-1/jan jun1999.html\#iraq and Unclassified Report to Congress, January-June 2001, Section on Iraq:

https://www.cia.gov/library/reports/archived-reports-1/jan jun2001.htm\#4 (all 28 May 2010)
} 
in Iraq." ${ }^{, 58}$ Since the Iraqis had no records of what they had destroyed in 1991 this could not be independently verified, but there were some grounds to trust Kamel: he led the UNSCOM inspectors to a large hidden cache of documents that the regime had tried to preserve and revealed that Iraq had in the past managed to weaponize biological agents (although the inspectors already knew about the existence of the BW programme). In the process Kamel had also put himself in danger; on returning to Iraq, he was shot dead by Saddam. ${ }^{59}$ His defection might therefore have prompted at least a degree of reassessment ${ }^{60}$ - but in the end it had no discernable impact on the CIA's analysis. None of the Agency's unclassified reports to Congress during the Clinton years mentioned Kamel. According to Charles Duelfer, it was "manifestly clear to the intelligence community that the Clinton administration had a very strong incentive to find Iraq in violation of the UN sanctions" and this sometimes led them to use data that he describes as "pretty lame" or even "junk". 61

\section{The UNSCOM Saga}

To be sure, Saddam had not given the same level of co-operation to UNSCOM as he did to INVO. The problems faced by UNSCOM have dominated the debate over the inspections process and obscured the success of INVO. It is worth reviewing the UNSCOM saga here because the obstructionism regarding CBW does not seem to correspond with—and perhaps even casts doubt on-Iraq's co-operation on nuclear matters. But the UNSCOM process was

\footnotetext{
${ }^{58}$ Kamel debriefing transcript. Diamond calls Kamel's defection the single most important piece of intelligence on Iraq in this period. CIA and the Culture of Failure: 396

${ }^{59}$ Duelfer offers the following comment on whether Kamel could be trusted: "We knew he aspired to return to Iraq as its new leader. It would not be unreasonable for him to wish to have WMD when he got back" but argues that "hard evidence" was needed from the regime in Baghdad not from one of its defectors. Hide and Seek: 115

${ }^{60}$ Jervis also makes this point in Why Intelligence Fails: 137

${ }^{61}$ Ibid: 88-9.
} 
far more politicized than INVO. The UNSCOM story demonstrates what happens when a supra-national disarmament process becomes highly politicised and even manipulated by national governments in a way that did not occur with INVO. This political intrusion also offers a partial explanation for Iraq's lack of co-operation in some cases and its continued willingness to co-operate with INVO.

In 1991, Iraq unilaterally destroyed much of its WMD and made this known to the inspection teams. However, it had not done this under international supervision, as required by UN resolutions. The lack of documentation left UNSCOM with no way to verify the destruction other than literally digging up and piecing together fragments of destroyed weapons; a problem that plagued the CBW inspections process. ${ }^{62}$ Saddam had also instituted a programme of denial and deception in April 1991 to be carried out by the Concealment Operations Committee in an effort to secretly retain small amounts of material and a library of documents containing the scientific know-how. ${ }^{63}$ The lack of documentation and the concealment efforts meant there were holes in Iraq's declarations of its WMD and the UN was forced to ask repeatedly for 'Full, Final and Complete' declarations, which were rarely any of those. Some inspections of suspected CBW sites were subsequently blocked. Iraqi conduct therefore encouraged suspicions that it retained WMD. ${ }^{64}$

\footnotetext{
${ }^{62}$ Butler, Greatest Threat: 6-7, 51-2, 80, 150, 157-8.

${ }^{63}$ Ritter, Endgame: 104-9. Report of the Senate Select Committee on Intelligence on Postwar Findings About Iraq's WMD Programs and Links to Terrorism and How They Compare with Prewar Assessments (henceforth SSCI, Postwar Findings), 8 September 2006, http://intelligence.senate.gov/phaseiiaccuracy.pdf (29 May 2010): 120. Duelfer Report, Regime Strategic Intent Section: 1

${ }^{64}$ On Iraqi non-compliance see Duelfer, Hide and Seek: 91-110; Butler, Greatest Threat: 160-61, 164, 204, 206-7; Blix, Disarming Iraq: 264.
} 
Unbeknownst to UNSCOM at the time, however, the Concealment Committee also quickly ordered the unilateral destruction of what secretly remained of Iraq's WMD in 1991 (as later reported by Hussein Kamel). The regime had thought that the inspections would be over in a matter of weeks, but it quickly became clear that they would be longer lasting and more intrusive than this. Saddam's priorities were the survival of his regime and the removal of sanctions. As a result he took what the CIA retrospectively described, years later, as his "fateful decision": in 1991 the Concealment Committee was ordered to unilaterally destroy the small stockpiles that had not been declared to the UN and to retain only a secret library of information that might be of use in the future. In doing so, however, the regime also destroyed documentation that could have verified the destruction of the remaining weapons later on, thus creating the perception that small amounts of WMD might remain. ${ }^{65}$

Why, then, did Saddam fail to give full co-operation to the UNSCOM inspectors when there were so few, if any, CBW left to hide? Blix and Duelfer — who both had opposing views on regime change—-believe there were other possible explanations for Saddam's recalcitrance. Among the most important was that Iraq wanted others in the region, especially Iran, to believe it had WMD. As the Duelfer Report concluded in 2004: "Iran was the prime motivator of this policy." The two countries had been at war from 1980-88 and all senior level Iraqi officials still considered Iran to be their principal enemy. The wish to balance Israel and acquire status and influence in the Arab world were also contributing factors. Tariq Aziz openly expressed hostility to both Israel and "the Persians" to Richard Butler in early $1998 .{ }^{66}$ This was a political

\footnotetext{
${ }^{65}$ SSCI Postwar Findings: 130-31. Blix, Disarming Iraq: 257. Butler, Greatest Threat: 51

${ }^{66}$ Blix, Disarming Iraq: 266. Duelfer Report, Regime Strategic Intent: 1. In his infamous July 1990 meeting with US ambassador to Iraq, April Glaspie, Saddam expressed concern at (in Glaspie's words) "mortal threats from Israel and Iran". Cable 90BAGHDAD4237, Secret, Saddam's Message of Friendship to President Bush, 25 July 1990, http://213.251.145.96/cable/1990/07/90BAGHDAD4237.html (7 January 2011). Butler, Greatest Threat: 118.
} 
calculation by Iraq, the deduction of which did not necessarily require secret intelligence; yet it was never even considered in the CIA's reports to Congress.

A second issue was the sanctions. In 1991, when they were imposed, Iraq was told that the sanctions would be removed if and when it co-operated with the UN inspectors according to UN Resolution 687. Despite the efforts to conceal documents and information, the majority of the inspections did pass off without incident and Iraq was particularly co-operative with INVO. Yet not only was there no sign of the sanctions being lifted or eased, the Clinton administration was covertly working towards the demise of Saddam. If there was no chance of sanctions disappearing and if the ultimate US objective was regime change, there was little incentive for Iraq to co-operate fully. ${ }^{67}$ Tariq Aziz told Duelfer at the time that he did not believe that Washington would accept a report from UNSCOM that might lead to the lifting of sanctions: "Therefore we have a simple choice: Iraq could have sanctions with inspectors or sanctions without inspections" he said. ${ }^{68}$ Duelfer also reports that in August 1998 Aziz made a proposal to Richard Butler, the new head of UNSCOM, that Iraq would permit inspectors of all types to have complete access anywhere in Iraq for six months. At the end of the six months, however, UNSCOM would have to declare Iraq in full compliance unless it found weapons material. "Aziz's point was that Iraq wanted closure, not an endless process" Duelfer writes. "He wanted UNSCOM to report to the Security Council so the council would have to confront the issue of removing sanctions. We did not give the idea serious consideration at the time because we thought it was simply a tactic to divide the Security Council." ${ }^{, 69}$

\footnotetext{
${ }^{67}$ Blix, Disarming Iraq: 265

${ }^{68}$ Quoted in Duelfer, Hide and Seek: 154

${ }^{69}$ Ibid, footnote 5, p. 491
} 
The humiliating nature of some of the inspections may also have affected Iraq's behaviour. The way that inspections were carried out became a bone of contention between Blix and David Kay. "Inspectors should always avoid humiliating the inspected" says Blix. Attacking Kay, Blix argues that

[A] Rambo-style attitude on the part of the inspectors antagonizes more than it intimidates. Inspection is not the pursuit of war by other means. Inspectors are not occupiers and should neither shoot nor shout their way in... To the Iraqi side, David Kay became like a red cape to a bull... ${ }^{70}$

This sense of humiliation might have been exacerbated by the particularly intrusive nature of the inspections, especially to sites associated with the sovereignty of Iraq. ${ }^{71}$ This was especially the case after 1997 when UNSCOM began to attempt to inspect some of Saddam's personal residences. The inspections of the so-called Presidential sites twice led Iraq to balk at the demands that were being made of it, requiring the intervention of UN Secretary General, Kofi Annan. ${ }^{72}$

Moreover, the UNSCOM inspections process was allegedly being subverted by the Clinton administration to aid its covert pursuit of regime change. Scott Ritter describes the CIA presence in the UNSCOM team until 1996 as "the ghost in the machine." inspections describes how CIA Special Activity staff, specialising in paramilitary operations,

\footnotetext{
${ }^{70}$ Ibid: 26. Similarly Charles Duelfer describes UNSCOM inspections as "akin to military operations without weapons." See Hide and Seek: 130

${ }^{71}$ Ibid: 265

${ }^{72}$ Ritter, Endgame: 157-175. Ritter played a leading role in pushing for these inspections. Blix, Disarming Iraq: 265. Hiro, Iraq: 115-6

${ }^{73}$ Ritter, Endgame: 131-46
} 
were made available to UNSCOM as inspectors. In June 1996, a team which included nine CIA agents attempted to inspect a Special Republican Guard (SRG) facility but were prevented from doing so by the Iraqis, who had discovered a coup plot against Saddam, which they believed was to be carried out at the time of the inspection by SRG members from the units UNSCOM was trying to inspect. Ritter's allegation was that the inspectors from the CIA-who vanished inexplicably after the contested SRG inspections-were complicit in the coup. Although UNSCOM's chief inspectors may not have been aware of this at the time, the response of Iraqi Deputy Prime Minister, Tariq Aziz, to Ekeus on June $19^{\text {th }}$ made it clear that the Iraqis certainly believed this was the case. ${ }^{74}$ This would be consistent with the Clinton administration's covert pursuit of regime change and would also explain Iraq's willingness to continue co-operating with the IAEA's nuclear monitoring. After June 1996, Iraq directed its resistance specifically towards UNSCOM inspectors from the United States (as opposed to those of other nationalities) and requested that the CBW inspection teams be reconstituted to reflect a wider range of nationalities. It was, however, still prepared to admit US nationals as part of the IAEA teams. ${ }^{75}$ There is no evidence at present, however, that the US IC ever considered these events from Baghdad's perspective. Resisting inspections out of a belief that the US was using them to aid its covert pursuit of regime change would certainly explain Iraq's behaviour in this case; but Saddam's failure to allow the inspection was viewed purely as another example of his determination to conceal his CBW arsenal.

\footnotetext{
${ }^{74}$ Ibid: 131-44. For Tariq Aziz's response, which is cited at length see pp. 139-41.

${ }^{75}$ Blix, Disarming Iraq: 31, 34. Butler writes that although Iraq was prepared to admit a US national who worked for the IAEA in November 1997—-when it was refusing entry to US nationals in UNSCOM-there was an agreement between UNSCOM and the IAEA that they should only enter Iraq together and so the US national returned to Bahrain. Greatest Threat: 95 and 91-2.
} 
By this stage, the neutrality of UNSCOM was also being compromised by illicit intelligence sharing with national intelligence services from the United States and elsewhere. Charles Duelfer later described UNSCOM as "a spy magnet" that included informers from many countries "for a variety of reasons beyond merely supporting UNSCOM.." ${ }^{, 76}$ Blix concurs that "activities had taken place under the label but not under the control of UNSCOM." $"$ Stories appeared in the press about how, unbeknownst to UNSCOM, the CIA had "piggybacked" on the work of the inspectors to covertly eavesdrop on the Iraqi military for three years. ${ }^{78}$ Established as a neutral and independent UN taskforce, its mandate was being violated by national governments engaging in espionage inside Iraq; a situation unlikely to please Baghdad. Yet despite the compromised position in which UNSCOM found itself, the CIA continued to attribute all friction between Iraq and the inspectors to Saddam's determination to maintain a WMD capacity. ${ }^{79}$

The default position of US intelligence and policy makers was that Saddam's denial and deception efforts meant that anything could be going on behind closed doors. Explaining his decision to use force against Iraq in Operation Desert Fox in December 1998, Clinton told the American public that "Saddam's deception has defeated [the inspectors'] effectiveness. Instead of the inspectors disarming Saddam, Saddam has disarmed the inspectors. ${ }^{" 80}$ In fact, the opposite was true. By 1995, after three years of very careful observation — and with help from

\footnotetext{
${ }^{76}$ Duelfer, Hide and Seek: 168-9.

${ }^{77}$ Blix comments: "As I read all these reports, which were published by indefatigable American investigative journalists, I had little doubt that the larger part, at any rate, was true." Disarming Iraq: 37.

78 'U.S. Spied on Iraqi Military Via U.N.' Washington Post, 2 March 1999. Blix Disarming Iraq: 37

${ }^{79}$ See the Unclassified Reports to Congress cited in footnotes 55-7.

${ }^{80}$ Transcript: President Clinton Explains Iraq Strike, CNN.com, 16 December 1998, http://edition.cnn.com/ALLPOLITICS/stories/1998/12/16/transcripts/clinton.html (30 May 2010)
} 
US and Israeli intelligence - the inspectors had finally unravelled Iraq's concealment mechanism and were attempting to counter it. ${ }^{81}$ Ritter and his colleague, Nikita Smidovich of Russia, had determined that Iraq had a network of hiding places, a fleet of trucks with which to transport the libraries of information it was still trying to preserve and that it relied on early warnings of where the inspectors planned to go. From 1996 onwards, Ritter and Smidovich began planning some inspections on the basis of this information in order to thwart Iraqi obfuscation. ${ }^{82}$ This, therefore, gave the conclusions of UNSCOM — that Iraq was largely disarmed — even greater force because their results had been achieved in spite of Iraq's concealment efforts.

Thus the common narrative of intransigent Iraqi obstructionism is not entirely accurate and the disconnect between the fractious UNSCOM inspections and the successful IAEA monitoring, though real, is less pronounced than is often assumed. The politicization of UNSCOM offers at least a partial explanation as to why some of its inspections were blocked and why the Iraqis continued to co-operate with the nuclear OMV. Yet US intelligence reports relied on an unchanging, default view of Saddam as a determined regional aggressor. There seemed to be no distinction made between the work of UNSCOM and that of the IAEA. The denuclearisation of Iraq was a huge success yet Clinton invoked Iraq's nuclear programme three times in his address to the nation before Desert Fox, as well as Iraq's alleged "military capacity to threaten its neighbours"-an unlikely prospect given the success of the inspections and the demise of Iraq's industrial base ${ }^{83}$ To the Clinton administration, Iraq appears to have

\footnotetext{
${ }^{81}$ Ritter, Endgame: 118-30. 'Arms Inspectors "Shake the Tree": UNSCOM Adds Covert Tactic' Washington Post, 12 October 1998. Peter J. Boyer, 'Scott Ritter's Private War', The New Yorker, 9 November 1998: 56-73

${ }^{82}$ These efforts are also described in Duelfer, Hide and Seek: 117-135.

${ }^{83}$ Transcript: Clinton Explains Iraq Strike'
} 
remained the chief 'rogue state.' It had been designated as such before Clinton even came to power and this was reinforced by the fact that US military posture was designed to fight two Desert Storm-sized conflicts simultaneously. This appears to have led to a mindset in which the assumption of Iraqi aggression and its maintenance of WMD was never questioned by the President and his advisors, by the IC or by Congress. Since 1992, the United States and Britain had been policing the 'no-fly zones' — illegal under international law—-through regular bombings and by 1999 this had become a low-level air war. ${ }^{84}$ In 1998, Congress passed the Iraq Liberation Act, making it official US policy to work towards regime change in Iraq. So uncontroversial was the measure that it was passed under suspension of the rules in the House and Unanimous Consent in the Senate, meaning that both parties agreed to its passage without any debate at all. ${ }^{85}$ In Iraq, however, this was viewed as further proof that the United States was no longer serious about the UN disarmament process or the lifting of sanctions. ${ }^{86}$

\section{The Bush Administration and Regime Change}

It was not just Clinton and his advisors that saw the benefits of regime change in Iraq. From the very beginning of George W. Bush's time in office, policy towards Iraq preceded intelligence. Even before 9/11, Bush and his advisors stated their preference for regime change. Donald Rumsfeld, Secretary of Defense, and his deputy, Paul Wolfowitz and other Bush advisors had

\footnotetext{
${ }^{84}$ For a comprehensive account of US and UK air strikes in the no-fly zones, see Douglas M. Brattebo, 'The No-Fly Zones and Low Intensity Conflict with Iraq, 1991-2003' in John Davis (ed.) Presidential Policies and the Road to the Second Iraq War (Ashgate, Aldershot and Burlington, 2006): 208-240.

${ }^{85}$ Iraq Watch, Iraq Liberation Act of 1998, Bill Summary and Status for the $105^{\text {th }}$ Congress, http://www.iraqwatch.org/government/US/Legislation/ILA.htm (30 May 2010)

${ }^{86}$ Duelfer, Hide and Seek: 156
} 
openly stated their support for regime change in Iraq during the Clinton years. ${ }^{87}$ Although Iraq was not a particular issue in the 2000 Presidential campaign, the aspirations of the Republican Party were stated unequivocally in its Platform:

A new Republican administration will patiently rebuild an international coalition opposed to Saddam Hussein and committed to joint action.... We support the full implementation of the Iraq Liberation Act, which should be regarded as a starting point in a comprehensive plan for the removal of Saddam Hussein and the restoration of international inspections in collaboration with his successor. Republicans recognize that peace and stability in the Persian Gulf is impossible as long as Saddam Hussein rules Iraq. ${ }^{88}$

Having a long-term objective should not be confused with having the opportunity to pursue it, but Bush's pre-9/11 policy deliberations confirm what the ultimate aim was towards Iraq. At the first meeting of the National Security Council on 30 January 2001, Iraq was the first item on the agenda. Rumsfeld, who had publically declared his support for regime change in 1998, hypothesized: "Imagine what the region would look like without Saddam and with a regime that is aligned with U.S. interests. It would change everything in the region and beyond. It would demonstrate what U.S. policy is all about." ${ }^{, 89}$ On February 6, Bush announced that the U.S. would resume funding opposition efforts inside Iraq for the first time since the Iraqi army

\footnotetext{
${ }^{87}$ Project for the New American Century, Letter to President Clinton, 26 January 1998, http://www.newamericancentury.org/iraqclintonletter.htm (2 June 2010). Maria Ryan, Neoconservatism and the New American Century (Palgrave Macmillan, New York 2010): 91-110.

${ }^{88}$ GOP Platform, section titled 'The Middle East and Persian Gulf' http://www.pbs.org/newshour/bb/election/july$\underline{\text { dec00/platform7.html }}$

${ }^{89}$ Cited in Ron Suskind, The Price of Loyalty: George W. Bush, the White House and the Education of Paul O'Neill (Simon \& Schuster, New York 2004): 85
} 
overran the rebels' main base in $1996 .{ }^{90}$ Plans were also made for some rebels to receive limited military training in Texas in March. "This is important because this is the first time we are receiving lethal training with the United States government funding," said Francis Brooke, a Washington representative of Iraqi National Congress that had been behind the failed coup of 1995. ${ }^{91}$ Ten days later, the administration undertook the most extensive bombing of Iraqi positions since December $1998 .^{92}$

There was no clear-cut consensus on how to deal with Iraq at this stage, however. An interagency group on Iraq was established by the administration and led by Richard Hass, director of Policy Planning at the State Department, which suggested supporting the INC's plan for US support for an uprising by Iraqi rebels and exiles. This was considered from late April to the end of July in deputies' meetings of high-ranking CIA officials, Deputy Secretary of State Richard Armitage, Wolfowitz and Vice-President Dick Cheney’s national security adviser, Lewis Libby, and in the Principals Committee of Condoleezza Rice, the National Security Advisor, Cheney, Powell, now Secretary of State, and George Tenet, the CIA chief. ${ }^{93}$ Wolfowitz, pressing the activist agenda, proposed the bombing of dams to recreate the marshlands in Iraq and, with his assistant, Zalmay Khalilzad, drafted further proposals for the arming and training of insurgents; the strategy they had supported since the late nineties. ${ }^{94}$

\footnotetext{
${ }^{90}$ Nicholas Arons, 'US Supported Iraqi Opposition', Foreign Policy In Focus, April 2001: http://www.fpif.org/briefs/vol6/v6n10iraq.html (20 February 2008)

91 'Iraqi Dissidents to Undergo Weapons Training in Texas', The White House Bulletin, 13 February 2001. Lake, "US to Give Iraq Rebels Weapons, Security Training”, United Press International, 13 February 2001

92 “Is There a Strategy?” Inter Press Service, 20 February 2001, reprinted at http://www.highbeam.com/doc/1P142047216.html (31 January 2010) Alan Sipress and Dan Balz, "Bush Signals Escalation in Response to Hussein”, Washington Post, 17 February 2001.

93 "US Considers Iraqi Coup", NewsMax.Com Wires. Lewis D. Solomon, Paul Wolfowitz: Visionary Intellectual, Policymaker, Strategist (Praeger Security International, Westport, Connecticut and London, 2007): 89

94 Zalmay Khalilzad and Paul Wolfowitz, 'Overthrow Him!' The Weekly Standard, 17 November 1997: 14-15
} 
Rumsfeld, however, was skeptical of the utility of further covert action in Iraq and called instead for the bolstering of the no-fly zones. Thus while "A Liberation Strategy" was completed on 1 August, no specific recommendations were put to the President. ${ }^{95}$ What it did indicate, though, was that regime change in Iraq was under discussion before $9 / 11$, albeit not as the administration's top priority. As in the Clinton years, policy would not be driven by the reality of a denuclearized Iraq, which had been stripped of most of its other WMD too. It would be driven by Rumsfeld's call to "demonstrate what U.S. policy is all about" in the Middle East.

It was no surprise, then, that just five hours after the attacks on New York, Washington and Pennsylvania, Rumsfeld called for "Best info fast. Judge whether good enough to hit S[addam] $\mathrm{H}$ [ussein] at same time. Not only O[sama] B[in] L[aden]... Go massive. Sweep it all up. Things related and not". ${ }^{96}$ Within days, the Pentagon had established the Policy CounterTerrorism Evaluation Group to cherry-pick intelligence that might link Iraq with al Qaeda, the group responsible for the 9/11 attacks. This was later expanded into the larger Office of Special Plans. ${ }^{97}$ The second pillar of the case for war was that Saddam Hussein possessed large stockpiles of WMD and had an active nuclear program with which he could support terrorists. (The distinction should be made between actual possession of such weapons, which constituted the Bush administration's rationale for war, and the aspiration to develop them if and when conditions permitted, which was Iraq's position.)

\footnotetext{
${ }^{95}$ Solomon, Paul Wolfowitz: 89

96 'Plans for Iraq Attack Began on 9/11', CBS News, 4 September 2002, http://www.cbsnews.com/stories/2002/09/04/september11/main520830.shtml (31 January 2010)

${ }^{97}$ Senate Report on Intelligence Activities Relating to Iraq Conducted by the Policy Counterterrorism Evaluation Group and the Office of Special Plans Within the Office of the Undersecretary of Defense for Policy, June 5, 2008, http://intelligence.senate.gov/pdfs/110346.pdf (18 January 2011). Jeffrey Goldberg, 'The Unknown', The New Yorker, 10 February 2003, http://www.newyorker.com/archive/2003/02/10/030210fa fact (30 May 2010).
} 
In spite of the success of INVO, George Tenet, the Director of the Central Intelligence (DCI) told the Senate Select Committee on Intelligence in February 2002 — just a week after Bush's "axis of evil" speech-that:

We believe that Saddam never abandoned his nuclear weapons program. Iraq maintains a significant number of nuclear scientists, program documentation, and probably some dual-use manufacturing infrastructure that could support a reinvigorated nuclear weapons program. Baghdad's access to foreign expertise could support a rejuvenated program. But our major near-term concern is the possibility that Saddam might gain access to fissile material. (Emphasis added) ${ }^{98}$

Elements of this were not completely untrue but it constituted a worst-case scenario at the expense of the bigger picture of INVO's success. (The same was true of claims made about Iraq's CBW programmes ${ }^{99}$ ).

When the Bush administration made its determination to pursue regime change clear, the Intelligence Community generally fell into line and supplied information — often spurious, hypothetical or even completely false - that could support the push for war on the basis of Saddam's possession of WMD. According to Charles Duelfer, who saw much of this intelligence, the CIA was "piling wobbly assessments on top of wobbly assessments based on extrapolations from a few possible 'facts' at the bottom..."100 This information, in turn, was

\footnotetext{
${ }^{98}$ George Tenet, Testimony Before the Senate Select Committee on Intelligence, 6 February 2002, http://www.nytimes.com/2002/02/06/international/06TENET-TEXT.html?pagewanted=print

${ }^{99}$ On the alleged chemical weapons trucks, see Diamond, CIA and the Culture of Failure: $374-85$. False claims about biological weapons were supplied by a source codenamed 'Curveball'. See 'The Record on Curveball', National Security Archive Electronic Briefing Book, No. 234, edited by John Prados, November 5, 2007, http://www.gwu.edu/ nsarchiv/NSAEBB/NSAEBB234/index.htm (11 January 2011).

100 Duelfer, Hide and Seek: 89. See also pages 88, 212, 253, 422 and 470.
} 
often also exaggerated by senior policymakers. The IC's worst-case scenarios on Iraq provided the basis for many of the now-discredited claims made by policymakers about Iraq's nuclear programme and its other WMD. ${ }^{101}$ Since the nuclear disarmament had been the most successful aspect of the UN's work, it was not surprising that some of the most questionable and speculative claims made by the administration concerned the nuclear question.

In September 2002, Cheney stated that "[w]e do know, with absolute certainty, that [Saddam] is using his procurement system to acquire the equipment he needs in order to enrich uranium to build a nuclear weapon." "102 Cheney was referring to Iraq's purchases of aluminum tubes; a claim that became a central plank of the case for a reconstituted nuclear programme. In 2004, the Duelfer Report concluded that the tubes were most likely destined to produce conventional rockets and that there was no uranium programme. ${ }^{103}$ In mid-2002, however, the CIA told Congress that they were part of a nuclear weapons programme. The October 2002 National Intelligence Estimate (NIE) on Iraq's WMD—which furnished the official case for war — stated that

Most agencies believe that Saddam's personal interest in and Iraq's aggressive attempts to obtain high-strength aluminum tubes for centrifuge rotors... provide compelling evidence that Saddam is reconstituting a uranium enrichment effort for Baghdad's nuclear weapons program. ([The] D[epartment] $\mathrm{O}[\mathrm{f}] \mathrm{E}[$ nergy] agree[s]

\footnotetext{
${ }^{101}$ On the CIA's use of hypothesis-based analysis and the precedents for this, see Maria Ryan, 'Filling in the "Unknowns": Hypothesis-Based Intelligence and the Rumsfeld Commission', Intelligence and National Security, Vol. 21 (2), April 2006: 286-315.

102 'Top Bush Officials Push Case Against Saddam', CNN.com, 8 September 2002, http://archives.cnn.com/2002/ALLPOLITICS/09/08/iraq.debate/ (30 May 2010). 'Bush, Aides Ignored CIA Caveats on Iraq', Washington Post, 7 February 2004.

${ }^{103}$ Duelfer Report, Vol. 2, http://permanent.access.gpo.gov/DuelferRpt/Volume 2.pdf : 21-31.
} 
that reconstitution of the nuclear program is underway but assesses that the tubes are probably not part of the program.) ${ }^{104}$

From here, the claim made it into Powell's high stakes presentation of US intelligence to the UN Security Council in February 2003. ${ }^{105}$ In fact the analysts at the DoE did not agree that the tubes were part of a nuclear weapons programme. The Bureau of Intelligence and Research (INR) at the State Department also disagreed and did not even think that Iraq had a nuclear program. ${ }^{106}$ However, the CIA and the Defense Intelligence Agency (DIA) produced three papers on the aluminum tubes between August and September 2002, which claimed that there was little doubt that they were for anything other than a nuclear programme. ${ }^{107}$ Between July 2001 and July 2002, the CIA produced nine other assessments of the tubes which all came to the same conclusion and which were distributed only to senior level policy makers. ${ }^{108}$

In October 2002, the administration also began to publicize bogus claims that Iraq had tried to procure natural uranium (yellowcake) from Niger to support its nuclear programme. Rumours of the transaction had circulated for some time in the IC but in early October 2002 the US embassy in Rome received documents that allegedly proved the deal. When the State Department received the reports it passed them on to INR, which immediately suspected that

\footnotetext{
${ }^{104}$ Unclassified Report to Congress, January-June 2002, https://www.cia.gov/library/reports/archived-reports1/jan_jun2002.html\#4 (30 May 2010). National Intelligence Council, Iraq's Continuing Program for Weapons of Mass Destruction (subsequently Iraq NIE), October 2002, Key Judgements, http://www.dni.gov/nic/special_keyjudgements.html (30 May 2010)

${ }^{105}$ Transcript of Colin Powell's U.N. Presentation, 6 February 2003, http://edition.cnn.com/2003/US/02/05/sprj.irq.powell.transcript/ (30 May 2010)

${ }^{106}$ SSCI 2004: 86

${ }^{107}$ Reports specifically on the aluminium tubes were produced by the CIA on 1 August 2002 and in September 2002 and by the DIA in September 2002. See SSCI 2004: 93

${ }^{108}$ Ibid: $90-1$
} 
the documents were fake. When they were passed to the IAEA on $4^{\text {th }}$ February 2003, they were instantly recognised as forgeries - a judgement the CIA was itself then forced to acknowledge. However, on $16^{\text {th }}$ October 2002 , INR passed copies to a colleague at the CIA, who simply filed the documents away in a vault without any further distribution. ${ }^{109}$ That same month, the CIA's Office of Near East and South Asian Analysis (NESA) included the claim in classified handbook of reference material for senior policy makers and it also appeared in the October 2002 National Intelligence Estimate on Iraq's WMD. ${ }^{110}$ At the CIA's request, the claim was then removed from the President's Cincinnati speech on $7^{\text {th }}$ October 2002 but it resurfaced on 17th January 2003 when the CIA published a paper on the alleged nuclear programme for the Chair, Joint Chiefs of Staff, which stated that "reporting on Iraqi attempts to procure uranium from various countries in Africa in the past several years is another sign of reconstitution (of the nuclear programme). Iraq has no legitimate use for uranium." ${ }^{111}$ Finally, the claim was inserted into the President's 2003 State of the Union address, which was given to Tenet in advance but which he neglected to read. ${ }^{112}$

Finally, the CIA also attempted to bolster its claims about nuclear weapons by contacting Iraqi scientists using relatives living in the United States as intermediaries. Thirty scientists were contacted via their relations who had been briefed by the CIA and given specific questions to ask in order to fill in gaps in the CIA's knowledge. In total, thirty scientists gave the same message to the CIA: that Iraq's chemical, biological and nuclear programmes had long since

\footnotetext{
${ }^{109}$ Ibid: 57-8, 68. Blix, Disarming Iraq: 234

${ }^{110}$ SSCI 2004: 55. Iraq NIE.

${ }^{111}$ Cited in SSCI 2004: 62-3.

${ }^{112}$ Ibid: 64. George Tenet (with Bill Harlow), At the Center of the Storm: My Life at the CIA (HarperCollins, New York 2006): 696
} 
been abandoned. The agency ignored this and refused to disseminate the reports from family members to senior policy makers, instead suggesting that the scientists had all been lying. ${ }^{113}$

By this stage the findings of INVO and the ongoing monitoring were completely irrelevant. A political decision had been taken to pursue regime change in Iraq and the intelligence and facts were fixed around the policy. Duelfer writes:

I would later spend much time reining in analysts who came to Baghdad trying to investigate their prewar assessments. It took continuous attention to focus the effort on developing the story from the evidence in Iraq, not prewar assumptions in Washington. ${ }^{114}$

\section{Conclusions}

There is much to be learned in terms of intelligence and non-proliferation from the Iraq episode. On the one hand, Iraq provides a model for how to disarm a recalcitrant state. The Iraqi nuclear programme was nullified. From 1994, the only job left was ongoing monitoring and verification. This was in part down to assistance from US intelligence, which provided satellite images of nuclear sites discovered during the 1991 war. The CIA also gave assistance in unravelling Saddam's concealment programme. ${ }^{115}$ In sum, the inspectors did an outstanding job of disarming Iraq and received occasional but important help from US intelligence, which could assist from afar.

\footnotetext{
${ }^{113}$ Risen, State of War: The Secret History of the CIA and the Bush Administration (Free Press, New York 2006): 88-107.

${ }^{114}$ Duelfer, Hide and Seek: 336

${ }^{115}$ Diamond, CIA and the Culture of Failure: 1880-1. Butler, Greatest Threat: 66, 100
} 
For the most part, however, this success occurred in spite of US government intervention rather than because of it. The entire process was compromised from start to finish because US policy towards Iraq, from the 1991 war to the 2003 invasion, was hyper-politicised. Ultimately, the US goal was not simply disarmament but regime change and since the US was the dominant political force behind the punitive measures imposed on Iraq, the whole disarmament process became hyper-politicised too and, at times, used as a vehicle for US objectives rather than UN goals.

There were several strands to this hyper-politicisation. The assessments made by both intelligence analysts and policy makers in the United States seemed barely to change in response to events on the ground. Once Iraq had been designated an official US adversary in the early nineties, there was no deviation from the "rogue state" narrative from either analysts or policy makers. This seemed to be reinforced by the fact that the new post-Soviet defence posture would be based on fighting two such rogue states simultaneously with Iraq serving as the model for this. Currently available intelligence assessments suggest that at no stage did intelligence analysts - or, for that matter, policy makers - consider how US covert action in Iraq might affect Iraqi behaviour and attitudes towards the inspections. Any clues that might have prompted a reassessment were ignored or summarily dismissed in favour of a default view in which Saddam's actions were always driven solely by his determination to conceal stockpiles of WMD. This led to an unquestioned assumption that WMD had to exist. As Senator Jeff Sessions (R-AL) put it during Kay's 2004 testimony to the Senate: "We just felt it was so impossible that they didn't exist." ${ }^{116}$ By 1998, there was a bipartisan consensus in the US Congress that regime change should be the official US objective in Iraq because the United

\footnotetext{
${ }^{116}$ Quoted in Kay testimony: 15
} 
States could not tolerate a rogue leader like Saddam in a region that was so strategically vital, in which the United States itself sought to remain the dominant outside power.

Finally, in the short term, the use of CIA agents on the ground as inspectors, in contrast to the more useful contributions that US intelligence might be able to make from afar, contributed to the hyper-politicisation. In Iraqi eyes at least, this seems to have turned the process into an American pursuit of Saddam rather than an international disarmament programme.

When the Bush administration came to power it, too, was committed to enforcing the Iraq Liberation Act. It was not committed to an international disarmament programme because its ultimate objective was to pursue regime change. This resulted in intelligence that was heavily skewed by political imperatives. Ultimately, it is not in the CIA's remit to unilaterally enforce non-proliferation norms because that decision is a political one. In the case of Iraq, the US objective was not just disarmament but, in the long term, establishing a stable pro-American regime in Baghdad. As US tolerance of the Israeli and Indian nuclear deterrents demonstrates, it is the political standpoint of the regime that is most important to US policy makers. Thus, while improvements in intelligence collection and analysis are always salutary, the lesson from Iraq is that they will not result in better, more effective non-proliferation initiatives unless those initiatives happen to coincide with US interests as defined by policy makers. 